QUARTERLY TECHNICAL PROGRESS REPORT

FOR THE PERIOD ENDING MARCH 31, 2002

\title{
TITLE: FIELD DEMONSTRATION OF CARBON DIOXIDE MISCIBLE FLOODING IN THE LANSING-KANSAS CITY FORMATION, CENTRAL KANSAS
}

DOE Contract No. DE-AC26-00BC15124

Contractor: $\quad$ University of Kansas Center for Research, Inc. 2385 Irving Hill Road

Lawrence, KS 66044

DOE Program: $\quad$ Class II Revisited - Field Demonstrations

Award Date: $\quad$ March 8, 2000

Total Project Budget: $\quad \$ 5,388,683$

DOE Cost Amount: $\quad \$ 1,892,094$

Program Period: $\quad$ March 8, 2000 - March 8, 2006 (BP1 03/00-06/01, BP2 06/0103/05, BP3 03/05-03/06)

Reporting Period: $\quad$ January 1, 2002-March 31, 2002

DOE Project Manager: $\quad$ Daniel J. Ferguson, NPTO Tulsa, Oklahoma

Contractor Contact: $\quad$ Alan P. Byrnes

Kansas Geological Survey

1930 Constant Ave., Lawrence, Kansas 66047

email: abyrnes@kgs.ukans.edu

phone: 785-864-2177

Principal Investigators: $\quad$ Alan Byrnes (Program Manager Budget Period 1)

G. Paul Willhite (Program Manager Budget Periods 2\&3)

Don Green, Martin Dubois, Richard Pancake, Timothy Carr, W. Lynn Watney, John Doveton, Willard Guy, Rodney Reynolds, Rajesh Kunjithaya, Dave Murfin, James Daniels, Niall Avison, Russell Martin, William Flanders, Dave Vander Griend, Eric Mork, Paul Cantrell 


\section{DISCLAIMER:}

This report was prepared as an account of work sponsored by an agency of the United States Government. Neither the United States Government nor any agency thereof, nor any of their employees, makes any warranty, express or implied, or assumes any legal liability or responsibility for the accuracy, completeness, or usefulness of any information, apparatus, product, or process disclosed, or represents that its use would not infringe privately owned rights. Reference herein to any specific commercial product, process, or service by trade name, trademark, manufacturer, or otherwise does not necessarily constitute or imply its endorsement, recommendation, or favoring by the United States Government or any agency thereof. The views and opinions of authors herein do not necessarily state or reflect those of the United States Government or any agency thereof.

\section{ABSTRACT:}

Progress is reported for the period from January 1, 2002 to March 31, 2002. Technical design and budget for a larger (60-acre, $24.3 \mathrm{ha}$ ) $\mathrm{CO}_{2}$ demonstration project are being reviewed by the US DOE for approval. While this review process is being conducted, work is proceeding on well testing to obtain reservoir properties and on the VIP reservoir simulation model to improve model prediction and better understand the controls that certain parameters exert on predicted performance. In addition, evaluation of the economics of commercial application in the surrounding area was performed. In a meeting on January 14, 2002 the possibility of staging the demonstration, starting with a 10-acre sub-pattern flood was raised and the decision made to investigate this plan in detail.

The influence of carbon dioxide on oil properties and the influence of binary interaction parameters (BIP) used in the VIP simulator were investigated. VIP calculated swelling factors are in good agreement with published values up to $65 \%$ mole-fraction CO2. Swelling factor and saturated liquid density are relatively independent of the BIP over the range of BIPs used (0.08$0.15)$ up to $65 \%$ mole-fraction $\mathrm{CO} 2$.

Assuming a CO2 EOR recovery rate projected as being most likely by current modeling, commercial scale $\mathrm{CO} 2$ flooding at $\$ 20 / \mathrm{BO}$ is possible in the leases in Hall-Gurney field. Relatively small floods (240-320 acres, 4-6 patterns) are economically viable at $\$ 20 / \mathrm{BO}$ in areas of very high primary and secondary productivity ( $>14 \mathrm{MBO} /$ net acre recovery). Leases with moderately high primary and secondary productivity (>10 MBO/net acre recovery) can be economic when combined with high productivity leases to form larger floods ( $\geq 640$ acres, 9 or more patterns).

The poster at the 2002 American Association of Petroleum Geologists Annual meeting, April 1014, Houston, TX, by Martin K. Dubois, Scott W. White, and Timothy Carr entitled "Cogeneration, Ethanol Production, and Enhanced Oil Recovery: Model for Environmentally and Economically Sound Linked Energy Systems", was awarded the best poster for the Division of Environmental Geosciences at the AAPG Annual Meeting. This poster was placed on the project website at: http://www.kgs.ku.edu/PRS/Poster/2002/2002-6/index.html 


\section{TABLE OF CONTENTS}

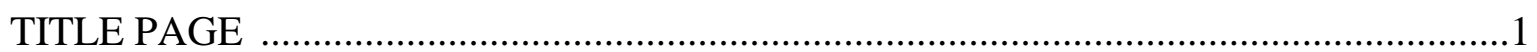

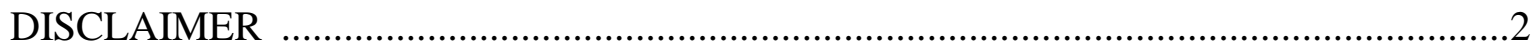

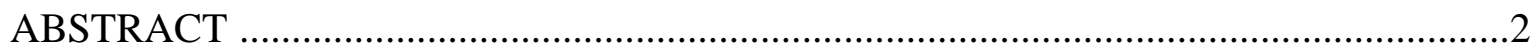

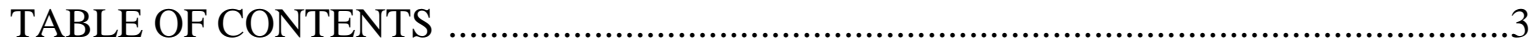

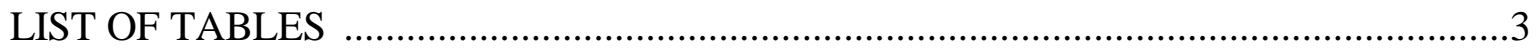

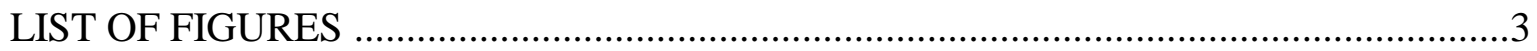

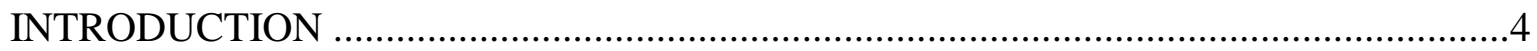

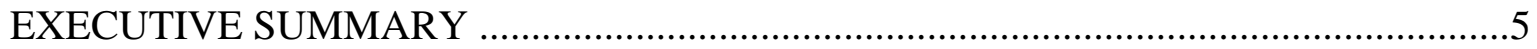

RESULTS AND DISCUSSION ............................................................................

Task 3.1 RESERVOIR SIMULATION …….............................................................

Effects of Carbon Dioxide on Swelling of Crude Oil ..................................................6

Task 3.2 ECONOMIC AND RECOVERY ANALYSIS OF PILOT ….......................

TASK 7.0 PROJECT MANAGEMENT ….............................................................. 10

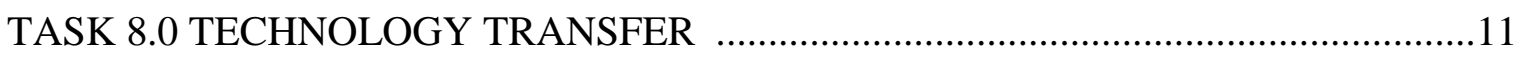

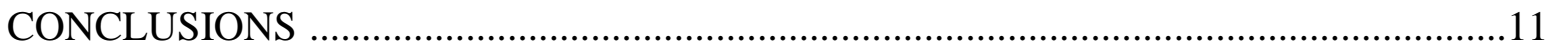

\section{LIST OF FIGURES}

Figure 1. Correlation of swelling with dissolved $\mathrm{CO} 2$.............................................6

Figure 2. Swelling factor vs mole fraction $\mathrm{CO} 2$ in Letsch oil ......................................... 7

Figure 3. Effect of BIP on swelling factor .......................................................... 7

Figure 4. Effect of BIP on saturation pressure .............................................................

Figure 5. Effect of BIP on density........................................................................

Figure 6. Economic patterns in adjoining leases in Hall-Gurney field ................................9

Figure 7. Annual production for selected leases in Hall-Gurney field near Pilot ................9

Figure 8. Rate of return vs oil price for selected Hall-Gurney leases ...............................10 


\section{INTRODUCTION}

Objectives - The objective of this Class II Revisited project is to demonstrate the viability of carbon dioxide miscible flooding in the Lansing-Kansas City formation on the Central Kansas Uplift and to obtain data concerning reservoir properties, flood performance, and operating costs and methods to aid operators in future floods. The project addresses the producibility problem that these Class II shallow-shelf carbonate reservoirs have been depleted by effective waterflooding leaving significant trapped oil reserves. The objective is to be addressed by performing a $\mathrm{CO}_{2}$ miscible flood in a 40 -acre (16.2 ha) pilot in a representative oomoldic limestone reservoir in the Hall-Gurney Field, Russell County, Kansas. At the demonstration site, the Kansas team will characterize the reservoir geologic and engineering properties, model the flood using reservoir simulation, design and construct facilities and remediate existing wells, implement the planned flood, and monitor the flood process. The results of this project will be disseminated through various technology transfer activities.

\section{Project Task Overview -}

Activities in Budget Period 1 (03/00-03/01) involve reservoir characterization, modeling, and assessment:

- Task 1.1- Acquisition and consolidation of data into a web-based accessible database

- Task 1.2 - Geologic, petrophysical, and engineering reservoir characterization at the proposed demonstration site to understand the reservoir system

- Task 1.3 - Develop descriptive and numerical models of the reservoir

- Task 1.4 - Multiphase numerical flow simulation of oil recovery and prediction of the optimum location for a new injector well based on the numerical reservoir model

- Task 2.1 - Drilling, sponge coring, logging and testing a new $\mathrm{CO}_{2}$ injection well to obtain better reservoir data

- Task 2.2 - Measurement of residual oil and advanced rock properties for improved reservoir characterization and to address decisions concerning the resource base

- Task 3.1 - Advanced flow simulation based on the data provided by the improved characterization

- Task 3.2 - Assessment of the condition of existing wellbores, and evaluation of the economics of carbon dioxide flooding based on the improved reservoir characterization, advanced flow simulation, and engineering analyses

- Task 4.1 - Review of Budget Period 1 activities and assessment of flood implementation

Budget Period 1 Extended to Allow Revised Flood Design Review and Additional Reservoir Characterization

Activities in Budget Period $2(\mathbf{0 3 / 0 2 - 0 3 / 0 5 )}$ involve implementation and monitoring of the flood:

- Task 5.1 - Remediate all wells in the flood pattern

- Task 5.2 - Re-pressure the pilot area by water injection

- Task 5.3 - Construct surface facilities

- Task 5.4 - Implement $\mathrm{CO}_{2}$ flood operations

- Task 5.5 - Analyze $\mathrm{CO}_{2}$ flooding progress - carbon dioxide injection will be terminated at the end of Budget Period 2 and the project will be converted to continuous water injection.

Activities in Budget Period $3\left(\mathbf{0 3 / 0 5 - 0 3 / 0 6 )}\right.$ will involve post- $\mathrm{CO}_{2}$ flood monitoring:

- Task 6.1 - Collection and analysis of post- $\mathrm{CO}_{2}$ production and injection data

Activities that occur over all budget periods include:

- Task 7.0 - Management of geologic, engineering, and operations activities

- Task 8.0 - Technology transfer and fulfillment of reporting requirements 


\section{EXECUTIVE SUMMARY:}

Progress is reported for the period from January 1, 2002 to March 31, 2002. Technical design and budget for a larger (60-acre, $24.3 \mathrm{ha}$ ) $\mathrm{CO}_{2}$ demonstration project are being reviewed by the US DOE for approval. While this review process is being conducted, work is proceeding on well testing to obtain reservoir properties and on the VIP reservoir simulation model to improve model prediction and better understand the controls that certain parameters exert on predicted performance. In addition, evaluation of the economics of commercial application in the surrounding area was performed. In a meeting on January 14, 2002 the possibility of staging the demonstration, starting with a 10 -acre sub-pattern flood was raised and the decision made to investigate this plan in detail.

The influence of carbon dioxide on oil properties and the influence of binary interaction parameters (BIP) used in the VIP simulator were investigated. VIP calculated swelling factors are in good agreement with published values up to $65 \%$ mole-fraction CO2. Swelling factor and saturated liquid density are relatively independent of the BIP over the range of BIPs used (0.080.15 ) up to $65 \%$ mole-fraction $\mathrm{CO} 2$.

Assuming a CO2 EOR recovery rate projected as being most likely by current modeling, commercial scale $\mathrm{CO} 2$ flooding at $\$ 20 / \mathrm{BO}$ is possible in the leases in Hall-Gurney field. Relatively small floods (240-320 acres, 4-6 patterns) are economically viable at $\$ 20 / \mathrm{BO}$ in areas of very high primary and secondary productivity $(>14 \mathrm{MBO} /$ net acre recovery). Leases with moderately high primary and secondary productivity (>10 MBO/net acre recovery) can be economic when combined with high productivity leases to form larger floods ( $\geq 640$ acres, 9 or more patterns).

The poster at the 2002 American Association of Petroleum Geologists Annual meeting, April 1014, Houston, TX, by Martin K. Dubois, Scott W. White, and Timothy Carr entitled "Cogeneration, Ethanol Production, and Enhanced Oil Recovery: Model for Environmentally and Economically Sound Linked Energy Systems", was awarded the best poster for the Division of Environmental Geosciences at the AAPG Annual Meeting. This poster was placed on the project website at: http://www.kgs.ku.edu/PRS/Poster/2002/2002-6/index.html

\section{RESULTS AND DISCUSSION:}

\section{TASK 3.1 RESERVOIR SIMULATION}

The VIP reservoir simulation model, utilized for predicting $\mathrm{CO}_{2}$ oil recovery, is being continuously refined to provide better prediction of the $\mathrm{CO}_{2}$ flood process. In this quarter the influence of carbon dioxide on oil properties and the influence of binary interaction parameters used in the VIP simulator was investigated. 


\section{Effect of Carbon Dioxide on the Swelling of Crude Oil}

The swelling behavior of $\mathrm{CO}_{2}$-Letsch oil was examined by simulating a swelling test using the parameters developed by fitting the PVT data for Letch \#7 using the Peng-Robinson EOS in VIP. In these simulations, the bubble point pressure was determined for a specified mole fraction of $\mathrm{CO} 2$ dissolved in oil and swelling factors were computed at each pressure. Results were compared with generalized correlations proposed by Simon and Graue ${ }^{1}$ shown in Figure 1 (Figure 8.39 from Whitson and Brule $^{2}$ )

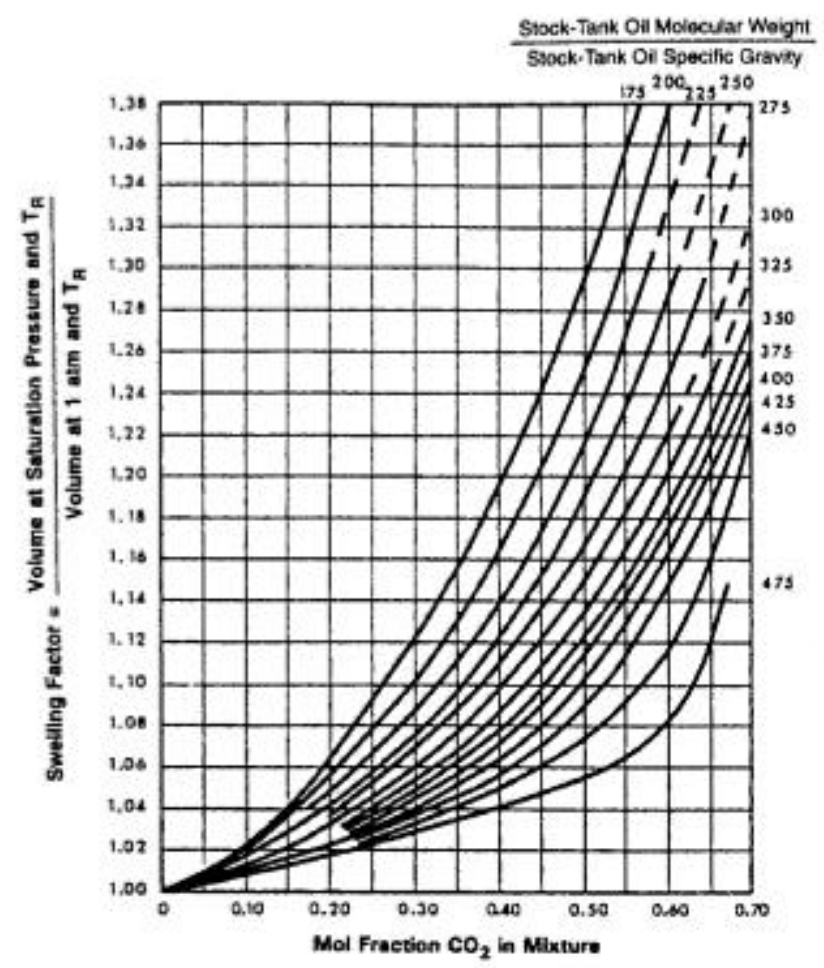

Figure 1. Correlation for swelling of a dead stock-tank oil when saturated with $\mathrm{CO}_{2}$ (Figure 8.39 Whitson and Brule ${ }^{2}$ after Simon and Graue ${ }^{1}$ ).

Figure 2 presents the swelling factor as a function of mole fraction of $\mathrm{CO}_{2}$ in the mixture. The solid blue diamonds represent data calculated by VIP program with binary interaction parameter (BIP) of $\mathrm{CO}_{2}$ and three heavy pseudo-components set at 0.12 . The red open circles represent data from the correlation with molar volume of oil at $225 \mathrm{cc} / \mathrm{g}$-mole. The molar volume of Letsch oil was 228 $\mathrm{cc} / \mathrm{g}$-mole. The calculated swelling factors are in good agreement with the correlation data up to $\mathrm{CO}_{2}$ mole fraction of 0.65 . 


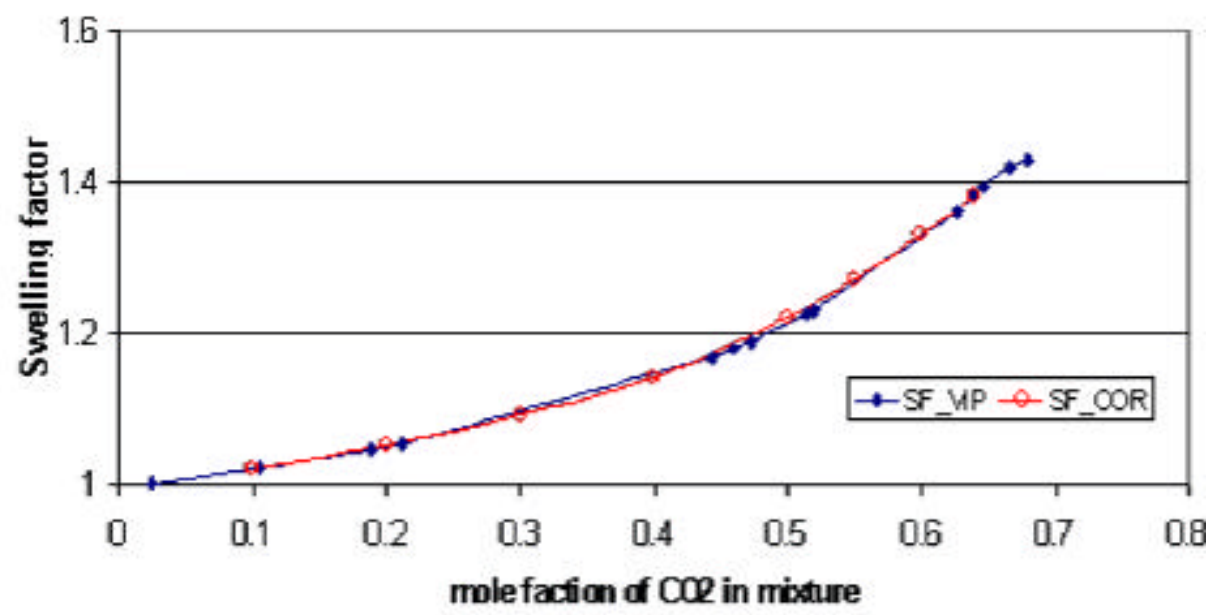

Figure 2. Swelling factor as function of mole fraction of $\mathrm{CO}_{2}$ in $\mathrm{CO}_{2}$-Letsch oil mixture.

Simulations performed to date have varied the value of BIPs to adjust the residual oil left after carbon dioxide miscible flooding. Figure 3 shows the effect of the BIP value on swelling factor for the Letsch EOS parameters. In the range of mole fractions from $0-0.65$, the calculated swelling factors do not depend on the value of BIP. Calculations using a BIP value of 0.08 predict the existence of a carbon dioxide rich liquid phase that has a swelling factor or 1.8. The composition of this liquid phase, if it exists, is $\sim 78$ mole $\%$ carbon dioxide. The effect of BIP on saturation pressure is presented in Figure 4.

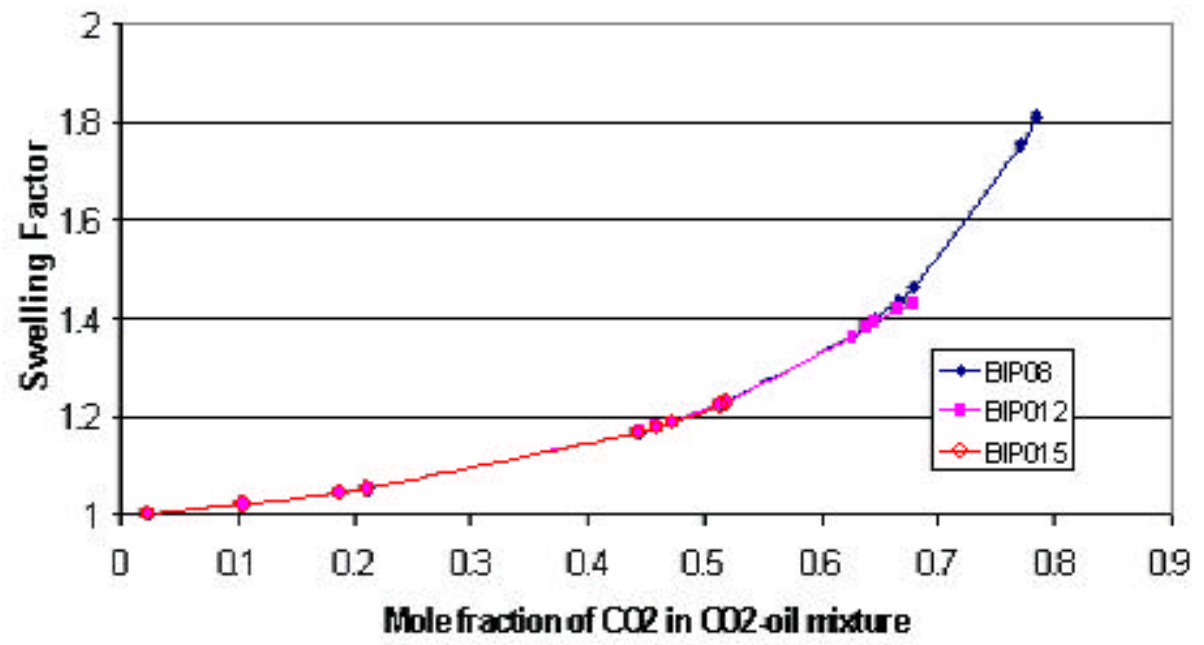

Figure 3. Effect of BIP on swelling factor

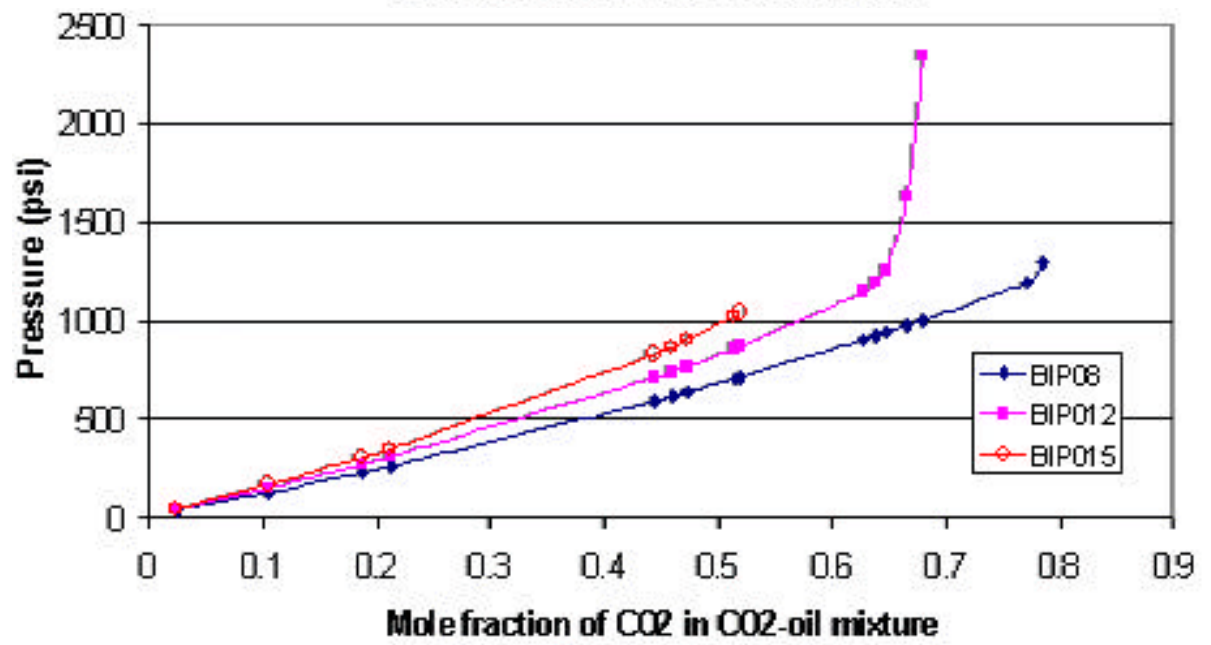

Figure 4. Effect of BIP on saturation pressure 
Figure 5 presents the effect of BIP on the density of the saturated liquid phase. Density of mixture generally decreases with mole fraction of $\mathrm{CO}_{2}$ in the mixture. This is consistent with the change in composition from a mixture that is rich in hydrocarbon to a mixture that is rich in carbon dioxide. With BIP of 0.12 , the density of mixture decreases initially, but increases from 0.81 to $0.825 \mathrm{~g} / \mathrm{cc}$ when mole fraction of $\mathrm{CO}_{2}$ increases from 0.64 to 0.68 .

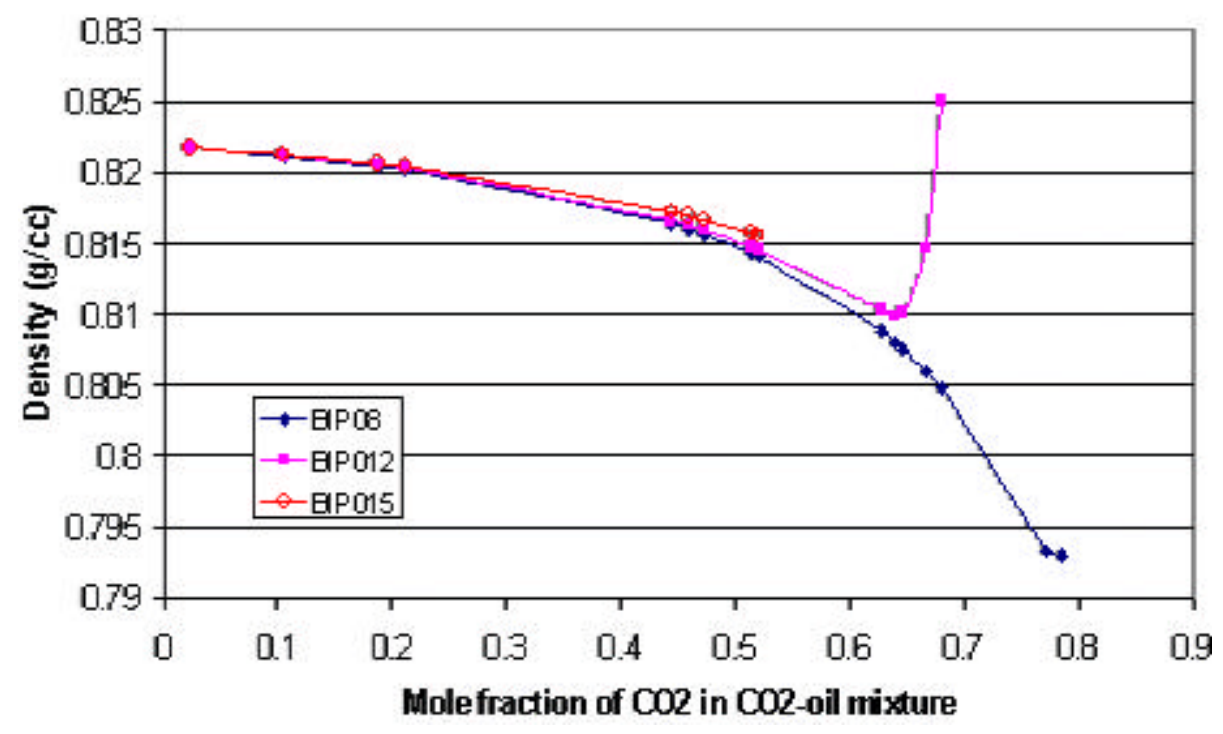

Figure 5. Effect of BIP on the density of the saturated liquid phase

\section{References}

1. Simon, R. and Graue, D. J.: "Generalized Correlations for Predicting Solubility, Swelling and Viscosity Behavior of $\mathrm{CO}_{2} /$ Crude Oil Systems", JPT(January 1965) 102; Trans. AIME, 234.

2. Whitson, C. H. and Brulé, M.R.: Phase Behavior, Monograph Series, SPE Richardson, Texas(2000) 20, 136.

\section{TASK 3.2 ECONOMIC AND RECOVERY ANALYSIS OF PILOT}

Approximate economics have been calculated for a variety of flood patterns, assumed reservoir properties, process rates, and operation plans for the pilot area. Analysis was conducted for surrounding leases and for other leases in the Hall-Gurney field. Highly productive areas (high recovery per acre) that were also good waterfloods are considered the most prospective for $\mathrm{CO} 2$ flooding in Central Kansas. Those leases having more than $9 \mathrm{MBO}$ per acre primary and secondary recovery may be considered prospective for CO2 EOR. Figure 6 shows leases in Hall Gurney that are prospective for CO2 EOR. Nearby leases including the Rein, Rogg, and Letsch leases exhibited higher primary and secondary production than the Colliver pilot site and are modeled to be more economic for $\mathrm{CO} 2$ flooding (Figure 7). 


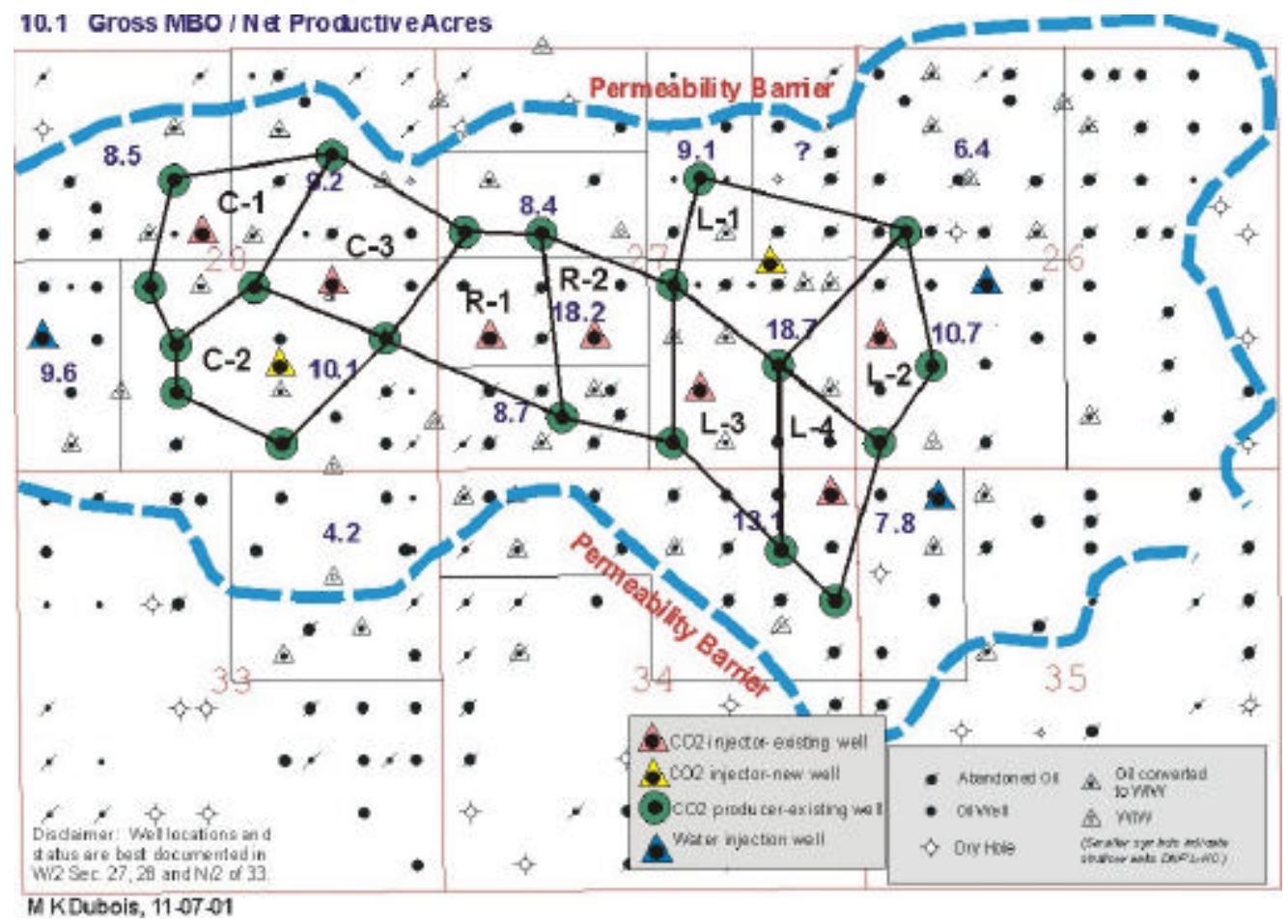

Figure 6. Potential Commercial patterns for leases in vicinity of Colliver Pilot area (shown as C2 in figure).

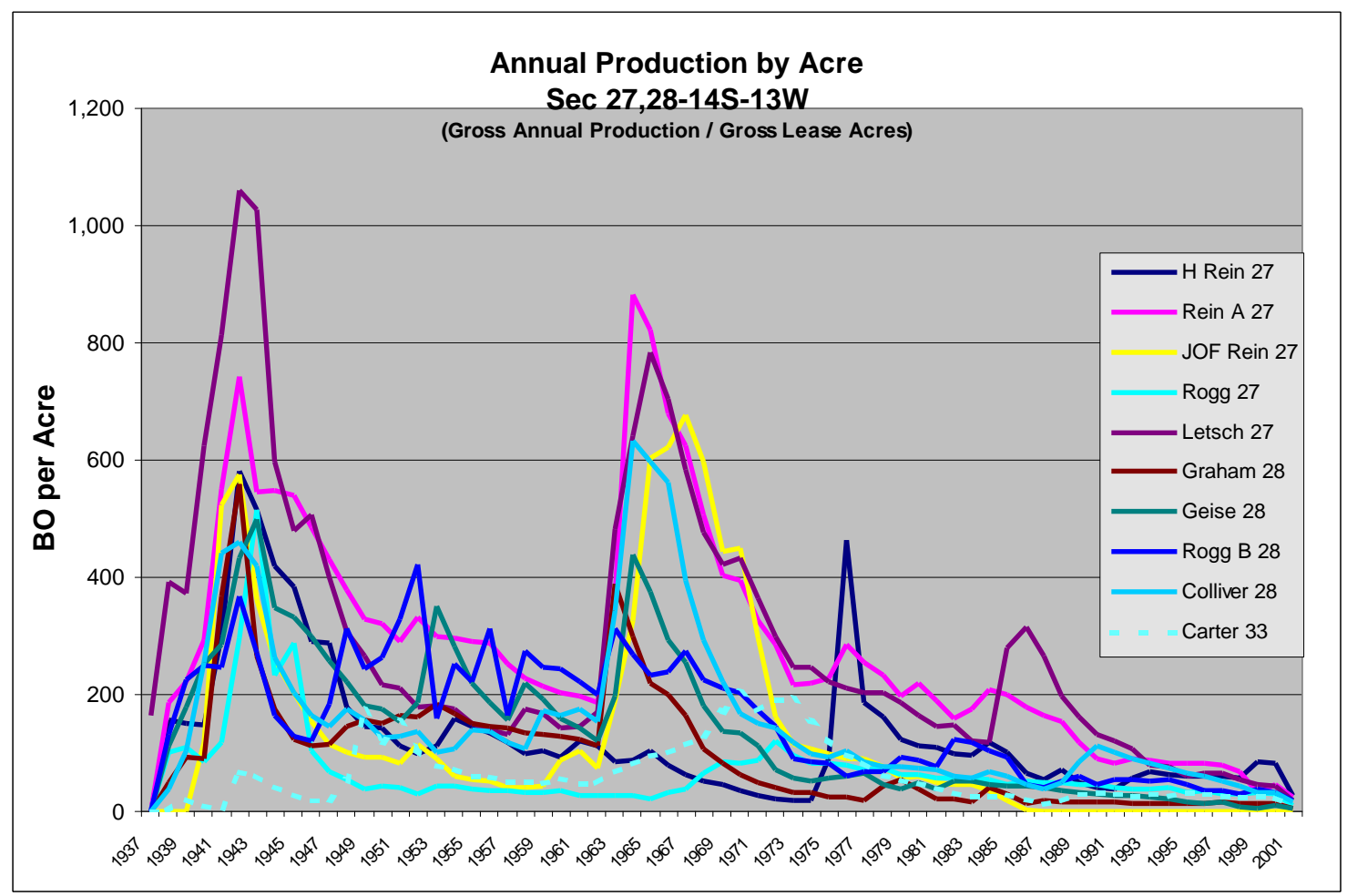

Figure 7. Annual production per acre of selected leases in Hall-Gurney near the Colliver Pilot site. 
Assuming a $\mathrm{CO} 2$ EOR recovery rate projected as being most likely by current modeling, commercial scale $\mathrm{CO} 2$ flooding at $\$ 20 / \mathrm{BO}$ is possible (Figure 8):

1. In relatively small floods (240-320 acres, 4-6 patterns) in areas of very high primary and secondary productivity (Letsch and Rein rates, $>14 \mathrm{MBO} /$ net acre recovery).

2. Areas with moderately high primary and secondary productivity (Colliver, $>10 \mathrm{MBO} / \mathrm{net}$ acre recovery) can be economic when combined with high productivity leases to form larger floods ( $\geq 640$ acres, 9 or more patterns).

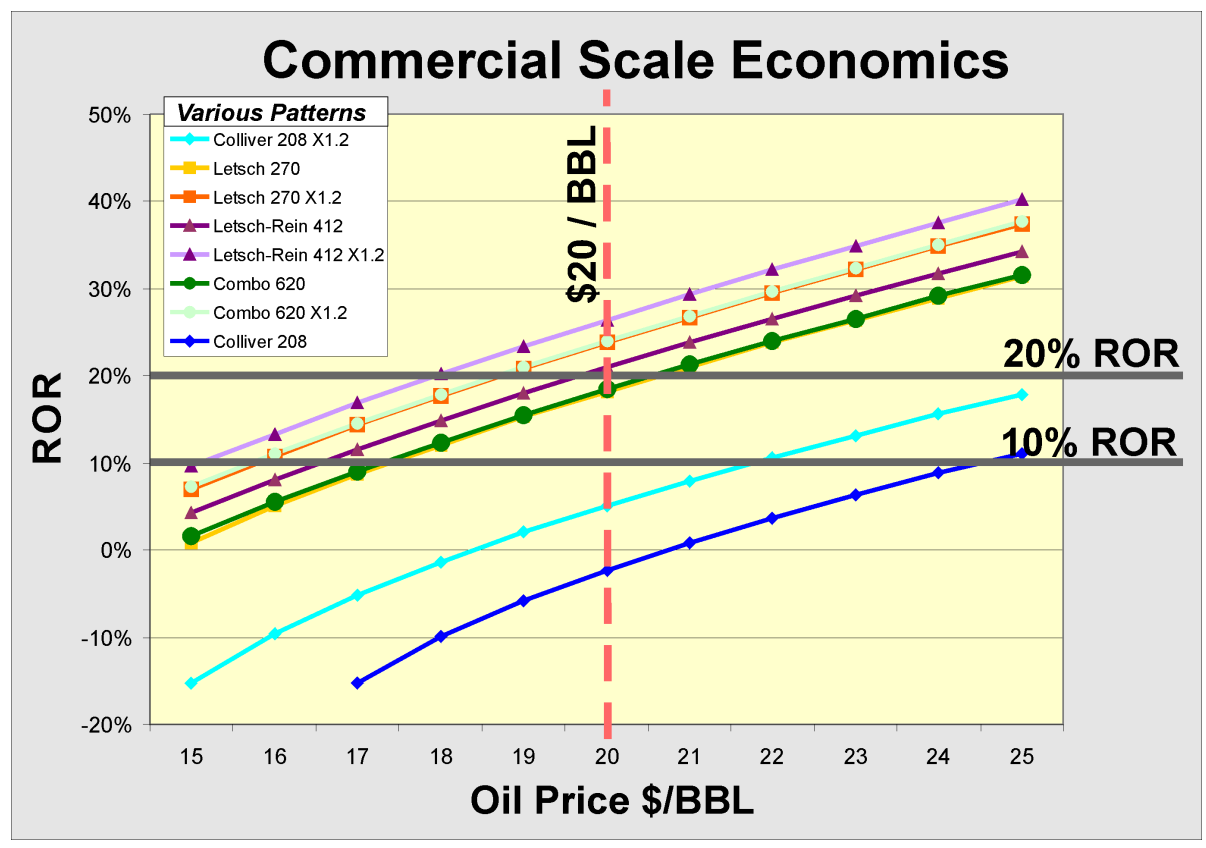

Figure 8. Rate of Return versus oil price for Hall-Gurney leases near Colliver Pilot area. Economics indicate that leases that performed better than the Colliver during waterflood are likely to be economic at oil prices equal to or greater than $\$ 20 /$ barrel.

Assuming a CO2 EOR recovery rate projected as being $120 \%$ of that predicted most likely by current modeling, commercial scale CO2 flooding at \$20/BO is possible:

1. On smaller floods (fewer patterns) given the same primary and secondary productivity

2. In relatively large floods of moderate primary and secondary productivity that would otherwise be uneconomic.

\section{TASK 7.0 PROJECT MANAGEMENT}

US Energy Partners is negotiating with companies for the sale of food-grade liquid CO2. Eight hundred (800) million cubic feet of $\mathrm{CO}_{2}$ are being held by US Energy Partners, the owners of the ethanol plant, for the demonstration pilot. Arrangements for how the $\mathrm{CO}_{2}$ will be transported and compressed for down-hole injection are being considered and will be finalized when a final $\mathrm{CO}_{2}$ sale agreement is reached. 
Two significant meetings were held in this quarter.

A meeting was held on January 14, 2002 at the offices of Murfin Drilling Company, Inc., Wichita, KS with the following personnel present: MV Energy) Dave Murfin, James Daniels; TORP) Paul Willhite, Don Green, Richard Pancake; KGS) Alan Byrnes, Martin Dubois; KinderMorgan) Donald Schnacke (rep K-M), and on speaker-phone William Flanders (Transpetco Engineering, rep K-M). Topics covered included: 1) Revised plan approval status, 2) Contacts and cooperation of adjoining lease operators; 3 ) Simulation model predictions of recovery and economics; 4) potential for economic expansion of pilot; 5) Possible alternate staged demonstration beginning with 10-acre and expanding to 60-acre design; 6) Current estimates of pilot economics. Significant consideration was given to 10 -acre pre-pilot and it was decided to evaluate this plan in detail. Technical evaluation of the 10-acre pilot has been conducted during this quarter and is being summarized.

A meeting was held on February 14, 2002 at the office of The Honorable Gary Sherrer, Lieutenant Governor/Secretary, in the State Capital in Topeka, Kansas with the following people present Gary Sherrer, Donald Schnacke, and Alan P. Byrnes. At the onset of the pilot project the Kansas Department of Commerce \& Housing (KSDOC\&H) provided \$100,000 of support for drilling of the first $\mathrm{CO} 2$ injection well. The meeting was to discuss additional support for the pilot project. The honorable Gary Scherrer agreed to continue support for the project with an additional $\$ 88,000$ from the KSDOC \&H for well reworking. Contracts were negotiated between Murfin Drilling and the KSDOC\&H during February and March to make these funds available to the project when well reworking begins.

Several small technical meetings were held with TORP and KGS personnel at the University of Kansas to discuss technical aspects of pilot and discuss details of 10-acre pilot evaluation.

\section{TASK 8.0 TECHNOLOGY TRANSFER}

A poster was presented at the 2002 American Association of Petroleum Geologists Annual meeting, April 10-14, Houston, TX, by Martin K. Dubois, Scott W. White, and Timothy Carr entitled "Co-generation, Ethanol Production, and Enhanced Oil Recovery: Model for Environmentally and Economically Sound Linked Energy Systems." This poster was awarded the best poster for the Division of Environmental Geosciences at the AAPG Annual Meeting. It has been placed on the project website at: http://www.kgs.ku.edu/PRS/Poster/2002/20026/index.html.

\section{CONCLUSIONS}

Progress is reported for the period from January 1, 2002 to March 31, 2002. Technical design and budget for a larger (60-acre, $24.3 \mathrm{ha}$ ) $\mathrm{CO}_{2}$ demonstration project are being reviewed by the US DOE for approval. Consideration is being given to staging the demonstration starting with a 10 -acre pilot flood and depending on the results of that pilot expanding to the presently proposed 60 -acre pilot. Technical evaluation of the 10-acre pilot is being performed. 
VIP calculated swelling factors are in good agreement with published values up to $65 \%$ molefraction $\mathrm{CO} 2$. Swelling factor and saturated liquid density are relatively independent of the BIP over the range of BIPs used (0.08-0.15) up to $65 \%$ mole-fraction $\mathrm{CO} 2$. Assuming a CO2 EOR recovery rate projected as being most likely by current modeling, commercial scale $\mathrm{CO} 2$ flooding at $\$ 20 / \mathrm{BO}$ is possible in the leases in Hall-Gurney field. Relatively small floods (240-320 acres, 4-6 patterns) are economically viable at $\$ 20 / \mathrm{BO}$ in areas of very high primary and secondary productivity (>14 MBO/net acre recovery). Leases with moderately high primary and secondary productivity (>10 MBO/net acre recovery) can be economic when combined with high productivity leases to form larger floods ( $\geq 640$ acres, 9 or more patterns). The poster at the 2002 American Association of Petroleum Geologists Annual meeting, April 10-14, Houston, TX, by Martin K. Dubois, Scott W. White, and Timothy Carr entitled "Co-generation, Ethanol Production, and Enhanced Oil Recovery: Model for Environmentally and Economically Sound Linked Energy Systems", was awarded the best poster for the Division of Environmental Geosciences at the AAPG Annual Meeting. This poster was placed on the project website at: http://www.kgs.ku.edu/PRS/Poster/2002/2002-6/index.html 